\title{
Supporting Individual and Society as One of the Principles of Citizenship Rights in Islamic Republic of Iran
}

\author{
Mohammad Saeed Shafiei ${ }^{1} \&$ Meysam Nematollahi ${ }^{1}$ \\ ${ }^{1}$ Faculty of Criminal Law and Criminology, Islamic Azad University of Shahrekord, Iran \\ Correspondence: Mohammad Saeed Shafiei, Faculty of Criminal Law and Criminology, Islamic Azad University \\ of Shahrekord, Iran. E-mail: mohammadsaiedshafiei@gmail.com
}

Received: September 2, 2016

Accepted: October 8, 2016 Online Published: November 30, 2016

doi:10.5539/jpl.v9n10p180

URL: http://dx.doi.org/10.5539/jpl.v9n10p180

\begin{abstract}
Citizenship rights is an obvious issue and one must defend the rights of citizens; but at the same time, we must consider the social realities of a society. When one speaks of the rights of citizens in a society, it does not mean to abide it and this right must be respected especially by government officials. To achieve this objective, the emphasis on understanding, implementation, and observance of citizenship rights should become as a culture and the government should do its supportive measures and efforts fairly and accurately so that social anomalies that are rooted in the lack of abiding citizenship rights, do not spread in the society. Therefore, it should be said that citizens, society, and the government are the three vertices if citizenship rights triangle, as the existence of all vertices is necessary. In this article, we discuss the concepts of citizenship rights and evaluate and assess the supporting principles of the individual and society which are considered as the government's duties. The reason for studying this issue is to find out why to support individual and society rights? Is this support a citizenship right? The aim of this study is to review citizenship rights including socio-political rights, economic rights and social welfare, judicial and cultural rights as well as supporting principles of the individual and society. To do this study, articles, and various books were studied and fundamentals of supporting the individual and society were developed and extracted. This review showed that supporting individual and community are including citizenship rights, and has been emphasized in all laws and international conventions.
\end{abstract}

Keywords: citizenship rights, citizen, government, support, society

\section{Introduction}

A school of thought that considers "the welfare in this world" as the goal of human life, leads all rights and duties to this path. The main task of the government is to ensure the welfare of citizens. However, some school of thought considers the unconditional freedom of citizens as necessary to meet this purpose and some other schools of thought believe in the abundant power of government and limited freedom of citizens to achieve the goal. But they all agree on the goal of "ensuring the welfare of mankind in the world". Fans of individualism, believe that individual happiness is the ultimate criterion of social life and one must not limit individuals' happiness in the name of society's interests unless the basis and foundation of society are at risk. Because the collapse of society will eliminate the individual. Fans of socialism also believe that although people are devoted to it, the authenticity, dignity, and power of the society and the public interests are precedences over individual interests and the law should primarily fulfill this aim; because, the suffering of people is worthless compared to the pride of the society (Mesbah Yazdi, 1999: 45).

Islamic viewpoint in this regard becomes clear according to the Holy Quran and the traditions and lifestyle of religious leaders. Islam respects the benefit and happiness and the interests of both individuals and the society and also the rights of the minorities. It does not limit the free will of society and government because of the "rights and freedoms of the individual"; as it does not neglect the rights and freedoms of the people for the "public interest". Of course, great importance is given to the community and public interests, which are considered as the interests of the majority of society; since human happiness and human rights and individual freedoms are considered in a healthy and balanced society. Through this introduction, we discuss the supporting of individual and society as one of the proven principles of citizenship rights and study its dimensions. 


\section{Citizenship Rights}

The rights of an individual and his duties toward the government are called "citizenship rights" and its interpretation is described by the constitution and civil laws of the country. Citizenship is the dignity of the individual in connection with a government that is respected from the perspective of international law. Each state laws determine the citizenship status. Therefore, a desirable citizen is a citizen that behaves responsibly; i.e. is responsible for his rights. Accordingly, the "citizenship rights" are the rights in which physical, spiritual, cultural, moral, political, economic and social status of citizens will be met and developed and it includes personal, social and civic, religious, and economic, political and judicial rights (Political Studies Office of the Islamic Consultative Assembly, 2012: 98). On this basis, citizenship rights is summarized below:

\subsection{Citizens' Political-Social Rights}

In the paragraph $6^{\text {th }}$ of Article III of the Constitution of the Islamic Republic of Iran, the elimination of all forms of despotism, dictatorship and monopolists; and in the paragraph $7^{\text {th }}$ of this Article, ensuring political and social freedoms and the government's commitment to using all possibilities for "public participation in determining the political, economic and its cultural future", as the most important tasks of government are all including cases that the legislator has considered for the political and social rights of people. Even denying legitimate freedoms in the name of preserving the independence and territorial integrity with the use of legal tools and legislation are including legislative strategies emphasized in Article IX of the Constitution.

\subsection{Economic Rights and Social Welfare}

Career choice and the feasibility of choosing a job in Article 28, having appropriate housing in Article 31, jobs and housing immunity from attack, preserving the possession of a person in Articles of 46 and 47, and enjoying social security in Article 29 are the including cases that the legislator considered as the economic rights and social welfare in the constitution.

\subsection{Legal Rights}

Eight articles of the Constitution of the Islamic Republic of Iran are allocated to citizens' legal rights: Articles 22, $32,34,35,37,38$, and 39 . The purpose of citizens' legal rights is to provide legal support for members of the society. We will discuss the details later.

\subsection{Cultural Rights}

Although legal supporting and equal enjoyment of all human rights in all political, economic, social, cultural aspects are considered in accordance with norms of Islam as a policy-driven citizenship rights in Article 20 of the Constitution, in specific articles, essential elements of cultural rights are not discussed openly; such as: cultural rights in the Constitution, granting rights in using regional and tribal languages in the press and in the mass media, and the teaching of local literature in schools alongside Persian for various ethnic groups living in Iran (Ghorbanzadeh, 2006: 29). In addition, paragraph $3^{\text {rd }}$ of Article III of the Constitution explains free education for all people at all levels and facilitating higher education. Moreover, the dissemination of education and free education up to secondary school with respect to the available facilities has been pointed out in Article 30 (Rostami, 2013: 145).

\section{Support and the Supportive Pillars}

According to the Constitution of the Islamic Republic of Iran in regard to the citizenship rights, the government has a duty to fully support the individuals according to laws, so that the three pillars of support: the public order, morality and the creation of public interest should be served. In this section, we examine these pillars.

\subsection{Establishing Public Order}

Study of social controlling in its various forms is one of the fundamental issues of social sciences; because the purpose of exercising social control is to maintain social order. Therefore, the way that society reacts to an abnormal or inappropriate, deviant or undesirable behavior is called social control. Government's supports for citizens' rights are fully compatible with the social order, and disobeying it, is the reason for violation of citizens against the government. Thus, in a mutual process, the government's support in favor of an individual leads to a society with discipline that minimizes the possible damages. Evaluating the role of public order as the aim of social control and criteria for activating the criminal law is a significant issue (Sadat Asadi and Mirzadeh, 2014: 67).

\subsection{Observing Ethical Materials}

Undoubtedly, ethics is the basic and starting point of offenses; because the expectations of people in a healthy 
community are to observe ethical norms and respecting citizens' rights and legislators also pay attention to these needs. In this respect, one of the most important results of government's support in favor of the individual and society is respecting the ethical issues (Sadat Asadi and Mirzadeh, 2014: 68).

\subsection{Creating Public Interest}

Bentham in 1776, in an article title "Government" considered utilitarianism as a major principle of the greatest happiness for the greatest number of people and as criteria for distinguishing between right and wrong. The most basic principle of utilitarianism is the estimation of "benefit and usefulness" of everything. Based on this criterion, one can say that the purpose of punishment is the prevention of crime and purpose of legitimacy is usefulness and necessity of protecting the public interest (Sadat Asadi and Mirzadeh, 1393: 70).

\section{Supporting Individuals}

Supporting individuals is synonymous with the observance of all rights that has been mentioned in constitutional laws and must be obeyed in accordance with society. The government must adhere to all individual rights based on human rights and Islamic teachings; some of these supports can be mentioned as follows:

\subsection{Supporting an Individual on His Power and Authority in Adopting the Government and Self-Determination}

According to the Article 6 of the Constitution, the country's affairs must be governed by referendum and this referendum can be carried out by"... the elections, the presidential election, Assembly elections, etc. ...". Thus, all the affairs of the country, either directly or through an indirect vote, depends on the will of the nation and there is no exceptions to this right. So one cannot limit the right in any way and restriction and limitation of this right are expressly contradicts with the principles of Islamic rules in paragraph 6 of Article II and Article 56 of the Constitution (Kousha, 2002: 19). Therefore, Article 56 states: "absolute sovereignty over the universe and man is God. And he has made man master of his own social destiny. No one can deny the divine right of man. Or serve the interests of a particular person or group... ". This fundamental right is called as "sovereignty of the nation ", which is clarifies the true will and right of citizens.

\subsection{Supporting Individual in Rights Equality}

Article 20 of the Constitution states that "all citizens, both men, and women, can equally enjoy the law and enjoy all human, political, economic, social and cultural rights in conformity with Islamic criterion". Equity which is explained to observe the principle of "Islamic principles" at the end of the Article 20, is the equality of human rights that can be granted, for Muslim or non-Muslim, men and women, respectively. For example the murder of non-Muslims or Muslims or in matters such as inheritance in which the share of the female is half of the male, or in Diya or blood money where female's Diya is half of the male's. Altogether, Article 20 is for all citizens (Divnava, 2013: 93).

\subsection{Supporting Individuals for the Rights of Having Jobs, Business and Job Security}

In principle, job is the essence of man and any person who finds the strength to work, should be able to engage in an occupation that is willing and competent. That is why Article 28 states: "The government is obliged to comply with society's needs for all different kinds of people, create equal conditions for obtaining jobs and the opportunity to work " (Piran, 1977: 24) . Thus, in a society where justice and equity prevails, anyone should be able to engage in a proper job in accordance with their ability. Basically, being unemployed and lack of employment opportunities is contrary to the mentioned Article.

\subsection{Supporting Individuals for the Rights of Having Jobs, Business and Job Security}

In principle, job is the essence of man and any person who finds the strength to work should be able to engage in an occupation that he is willing and competent in; that is why Article 28 states: "The government is obliged to comply with society's needs for all different kinds of people, provide create equal conditions for obtaining jobs and the opportunity to work" (Piran, 1977: 24). Thus, in a society where justice and equity prevails, anyone should be able to engage in a proper job in accordance with his or her ability. Basically, being unemployed and lack of employment opportunities is contrary to the mentioned Article.

\subsection{Supporting the Enjoyment of the Right in Healthcare, Health, Social Security and Insurance}

Article 29 states "enjoying social security with respect to retirement, unemployment, old age, disability, orphans, homelessness, accidents and the need for health services and medical care provided through insurance or other means is a universal right". The provisions of this Article is that the public, even the foreigners who live in our country have the right to enjoy these rights due to their citizenships, and the government is obliged under the law to provide financial services and support for country's citizens from the national revenues and funds obtained through public contributions (Sharifian, 2001: 66). 


\subsection{Supporting the Enjoyment of Free Education}

Since education and training plays an important role in human beings and the country's spiritual and material evolution, special attention had been paid to this issue in the Constitution of Iran. Article 30 states that: "The government must provide free education for all citizens up to secondary school." The provisions of this statement means that in higher education, the government has no obligation to maintain free education for all citizens but his duty is defined to the extent to resolve the country's needs (Vakil \& Askari, 2004: 86).

\subsection{Supporting the Right of Having Housing and Shelter}

Housing is the most essential human need. Without it, life would be difficult or impossible. According to Article 33 "housing is the right of every Iranian citizen; the government is obliged to implement this priority to those who are more needy, especially villagers and workers". Focusing on this principle, we understand that appropriate housing is a right for Iranian citizens but it does not conflict with the fact that the government meet the demands for housing homeless foreigners, if possible. Another point is that villagers and workers are the priority (Rostami, 2013: 150).

\subsection{Supporting Fair Justice}

Helping the oppressed is not only a religious duty, but it is also humanistic. Basically, human nature dictates that if someone was oppressed, anyone who has the power should help him and this kind of help is even a respect of citizens' rights. For this reason, Article 34 states "justice is the right of every person and each person can refer to competent courts for litigation". Therefore, it is the duty of the government to establish competent courts all over the country for the oppressed citizens. In this sense, all citizens have the right to have access to such courts and even no citizen can be prohibited from going to such courts. In this context, all citizens and even foreigners have equal rights like the Iranians (Pourahmadi, 2003: 11).

\subsection{Supporting Suspects and Offenders' Rights in Choosing the Lawyer}

According to Article 35, people can personally go to the courts. Each of the parties have the right to choose their own lawyer and no one and no authority has the right to prevent people from choosing the right lawyer; "even the government is required to provide people a lawyer if they do not have the ability to choose a lawyer". And in the criminal laws a lawyer will be given for the suspect, in some cases, such as crimes punishable by the death penalty or retribution. The wages of the accused are paid from the state budget. Provisions are considered so that people can make use of free lawyers; it is called as "legal assistance" (Najafi Abrandabadi, 1999: 39).

\subsection{Supporting the Freedom of Citizens in the Realm of Islamic Laws and Teachings}

Man is not only spiritually free, but has the freedom of the material, i.e. his desire to live in his own way. Article 32 states: No one shall be arrested except in accordance with the procedure determined by law". Therefore, temporary or permanent imprisoning, without proof of their crime is against the law and the perpetrator in a position will be punished. And if a person is charged with a crime, judicial or police has the right to summon him, and if there is a fear of his escape, he may be temporarily detained. Not only imprisonment but also punishing criminals must be according to the law and the orders of the court. Therefore, except the appointed competent judicial authority, no one can punish the guilty. And if so, in addition to punishment, moral and material damages suffered by the victim should be given either (Ghavam, 2010: 44).

\subsection{Supporting the Rights of Innocent People}

Article 37 states that no one is guilty; i.e. from the perspective of civic rights, the principle is presumption of being innocence; so no one is guilty in law, unless he is proved guilty by a competent court. This article is accepted based on pure nature of human in all legal systems worldwide (Ghavam, 2010: 46). Therefore, all citizens are presumed innocent, until the contrary is proved by a competent judge. Thus, accusing someone of a crime is against the law and it can be sued.

\subsection{Supporting Human Dignity of Citizens (Respect, Honor and Dignity)}

In this regard, Article 39 of the Constitution states: "Any belittled action on arrested, detained, imprisoned or exiled person is forbidden and the offender is liable to punishment". The punishment for the offender is determined by law and citizens can personally go to the courts for justice. So, if any of the authorities belittled citizens even if they are criminals, this violation is punishable (Goudarzi \& Boroujerdi, 2005: 109).

\subsection{Support of Iranian Citizenship}

Any Iranian citizen has the right to remain Iranian. Article 41 of the Constitution of the IRI, considered this indisputable right for every Iranian. The Iranian government cannot withdraw the citizenship; while in the 
constitution as well as some of the countries, some governments are entitled to perform permanent or temporary deprivation of citizenship as a punishment. However, from the perspective of current fundamental rights, deprivation of citizenship is possible by a court order or any other source. Since this issue concerns with a "right", the government should support it, and Iranian citizens are entitled to their citizenship rights, therefore, they can even ignore this right and accept the citizenship of another country. In this case and by the citizen's request, the government cannot withdraw citizenship. The importance of this issue is to the extent that if the foreigner is a citizen of Iran; as it is called "acquired citizenship", again, the government does not have the right to withdraw citizenship and it should support his citizenship (Ebrahimi, 2005: 63).

\subsection{Supporting the Right of Private Property}

Property is one of the obvious human rights. In Article 46: "Everyone has their own legitimate business..." and Article 47: "Private ownership, acquired legitimately is to be respected and its conditions are specified by law". Of course there are rules and restrictions for the better application of these rules, so the predicted laws will be applicable by a vote of the people and the government should support it.

\subsection{Supporting Individuals to Sue the Government and Governmental Institutions}

Ordinary, government and state have superior power and this causes trampling the rights of citizens if it is not adequately monitored. Therefore, one of the responsibilities of governments is to support the rights of citizens in cases that the government has been assaulted him. The fundamental rights derived from Article 90 which states that "Everyone whom has a complaint concerning the work of the parliament, or the executive, or judicial power can write his complaint to the Assembly". Moreover, according to Article 171 of the Constitution of IRI, if any settlement or decision approved by a government or government official is contrary to law and rights of people, everyone has the right to invalidate the acts by the Administrative Justice Court under the supervision of the Judiciary. Thus, the government is prevented to violate the rights of the people (Ebrahimi, 2005: 66). In citizenry, of course, the legal rights has been assumed for any person, and duties and responsibilities are considered beside these rights. So, certain behavioral patterns is expected. Moreover, theoretically, citizenry considers all citizens to have equal rights and in all circumstances government officials must consider this fact and support it; if not, they should be held accountable. In fact, the government is accountable to the citizens.

\subsection{Legitimate Freedoms and Contractionary Policies of Crime and Deviance}

Apparently the law has been approved in order to protect the legitimate freedoms. In general, though the word "legitimate" can indicate "credible and correct" legally, sometimes it means "conform to religious rules". The results concluded that the freedoms of law is respected in accordance with the law and it means that the unlawful freedom is not only respected, but also no supports is included and it will be condemned by the community; and as a result, it will be subjected to criminal laws (Yousef Zadeh, 2006: 93). In fact, the possibility of criminalization and distortion arises. In this case, decision-makers and law enforcement officials may infer on the basis of their own or possibly by resorting to analogy, under the scope of religion laws and as a result, there will be the respect for legitimate freedoms and preservation of civil rights.

\section{Supporting the Society}

In the constitutional laws, supporting the society is of great importance because society is suitable for the formation of people and developing the country's infrastructure to achieve the goals of the government. Accordingly, government's objective of supporting the society is summed up in two axes. In this paper, we discuss its details:

\subsection{Establishing Security in the Society through Preventive Measures and Fair Penalties}

In criminology, crime prevention is a practical science, so that the efficiency of theories and related theories are revealed only in practice and by an actual impact assessment and conducted measures. In the area of prevention, it is not subjected to a specific duty of one or more entities, but preventive measures should be carried out by all institutions of civil society such as family, school, religious institutions (mosques), local councils, NGOs, trade unions, associations and all state institutions such as the legislature, courts, police, social security institutions, municipalities and so on. In short, this achievement requires a clear and precise principles with regard to the different types of preventive measures and also explanation of specific duties of each of the authorities' esp. supervision of a scientific institution in charge, so that it will be able to link with all states and social authorities and give them the necessary guidance and training. Moreover, it should evaluate the effects of preventive measures to study the social and cultural conditions prevailing in the society, in order to change and replace the best preventive measures. On the other hand, deterrence based on the normative approach aims to strengthen the equity value, and in this regard, it is resorted to punishment in a sector, and in the other sector, it threatens to 
punish violators. This set of actions is considered as one of the functions of government's support in favor of society.

\subsection{Establishment of Social Welfare}

Social welfare is a term related to economic, social and political condition with the aim of protecting human dignity and responsibility of individuals to each other and enhancing the capabilities. The term "social welfare" refers to a state of social welfare, health, happiness, prosperity, well-being, and assistance, especially in the form of money, food, and other necessities that are provided to those in need, which are all the supportive tasks of the government. Overall, this concept means the state of being suitable (Mijeli, 1999: 4).

Indicators that are intended for social welfare in Iran are education, health, nutrition, housing, employment, population and labor, social security expenditure and income. In addition to the main indicators, several subsindicators are also being considered; including leisure activities, access to cultural facilities, environment and security of the person in case of aggressions (Masoud Asl, 2009: 87).

\subsubsection{Core Concepts in the Definition of Social Welfare}

Solving or controlling social problems; though there is no complete consensus on the concept and content of what is called social problem, there is consensus on issues such as unemployment, violence, drug abuse, poverty, suicide, and theft.

1) Supply needs; this concept evolved for decades, and in addition to its inclusion, aspects such as biological needs, housing, education, health and other needs essential for sensible life are also included.

2) Supply of equal social opportunities; this concept means equal opportunity in the employment, education, and social promotion, regardless of individual circumstances. In the case of inequalities in opportunities, the tendencies toward illegal and irrational methods to achieve the requirements will occur. The problem ultimately leads to an extension of the first area, i.e. the social affairs (Madani, 2000: 11).

\subsubsection{Social Welfare Patterns and Its Dimensions}

Social Welfare has the following four patterns: traditional, reestablishment of social justice, social development and a new paradigm of globalization. Social welfare encompasses several dimensions, including:

1) Biological dimension; including physical health (as opposed to disability and disease) and mental health (population, age pyramid, life expectancy, nutrition, etc.);

2) legal dimension; including laws protecting injured and vulnerable groups, laws relating to children and adults and women, criminal laws in cases of delinquency, youth, and social damage;

3) social dimension; including issues such as security, social skills, leisure, employment, family, social disorder, population, groups at risk: women and children, and social participation;

4) economic dimension; including poverty, security, economic development, employment, housing, subsidized payment system, charitable and non-profit economy, social justice, economic supporting of vulnerable groups, etc. (Zahedi Asl, 1994: 15)

\section{Conclusion}

In support of civil rights, effective and useful institutions are: Commission on Human Rights, the Administrative Court of the country, national inspection bodies, Article 90 Commission and the establishment of a national institution (Article 99 of the Citizenship Act) as its duty is educating and promoting the rights of citizenship, national and international awareness and support for the individual and society and citizenship rights, strict implementation and supervision of the civil rights. Supporting legitimate freedoms should be in accordance with the law, and actions contrary to the provisions of the law will be condemned and will along with criminal penalties. In political faction, law targeting has aspects of education and its tools are also very important. Issues of policy factions are subjected to the legal aspect of crime and the prohibition of arbitrary detention which is mentioned in accordance with Article 36 of the Constitution.

\section{References}

Civil rights and its promotion in the Fifth Development Plan. (2012). Political Studies Office of the Parliament.

Daems, T. (2007). Engaging with penal populism: The case of France. punishment and society, 9(3), 319-324. https://doi.org/10.1177/1462474507077578

Dobnaba, A. (2009). citizenship educational system, translation by Naderzadeh, Click Mag., No. 25.

Ebrahimi. (2005). the victim as plaintiff and his rights in criminal procedure of Iran. Justice Law Journal, 
$(52 \& 53)$.

Ghavam. (2010). the rights of victims and their demands from the police. social discipline Quarterly, (2).

Ghorbanzadeh. (2006). protecting civil rights in the light of the principles; master's thesis; Criminal Law and Criminology, Tehran University of Imam Sadeq (AS).

Goudarzi Boroujerdi, M. R. (2005). The Politics of Criminal Justice, Legal Assistance and the development of the judiciary, Publication of Salsabil.

Kousha. (2002). crimes against justice. Tehran: Publication of Mizan.

Madani. (2000). the comprehensive system of social welfare (1st ed.). Tehran University of Social Welfare and Rehabilitation Sciences.

Masoud Asl. (2009). the social welfare system in the world (1st ed.). Tehran, Iran: Majlis Research Center.

Mesbah-Yazdi, Mohammad Taghi. (1989). society and history in the Quran. Tehran: Center for Islamic Propaganda Organization.

Mijaliu, J. (1999). social welfare in the world, translation by Joghataee Tehran, Welfare and Rehabilitation Sciences University Press, first edition.

Najafi. (1999). pleadings of criminal policy lessons Ph.D., Tehran Shahid Beheshti University; Law School.

Piran, P. (1997). Tehran, economic and political magazine, Issue 4.

Pourahmadi. (2003). the right of compensation, Issue 37.

Rostami. (2013). civil rights and legitimate freedoms. Journal of Islamic jurisprudence and principles of law, 1(1).

Sadat Asadi, M. (2014). performance evaluation criteria for the protection of society against the criminal law.

Sharifian, J. (2001). the strategy of the Islamic Republic of Iran to the United Nations in the field of human rights, Printing, Publishing Printing \& Publishing Center of the Ministry of Foreign Affairs.

Vakil and Askari. (2004). constitution in the criminal policy (1st ed.). Majd Publications.

Yousefzadeh, H. (2009). Islamic social order, Marefat magazine, 103.

Zahedi Asl, Mohammad Reza. (1994). the concepts of social welfare and social security (Proceedings of the Seminar Sociology and Development) (1st ed., Vol. II). Tehran.

\section{Copyrights}

Copyright for this article is retained by the author(s), with first publication rights granted to the journal.

This is an open-access article distributed under the terms and conditions of the Creative Commons Attribution license (http://creativecommons.org/licenses/by/4.0/). 